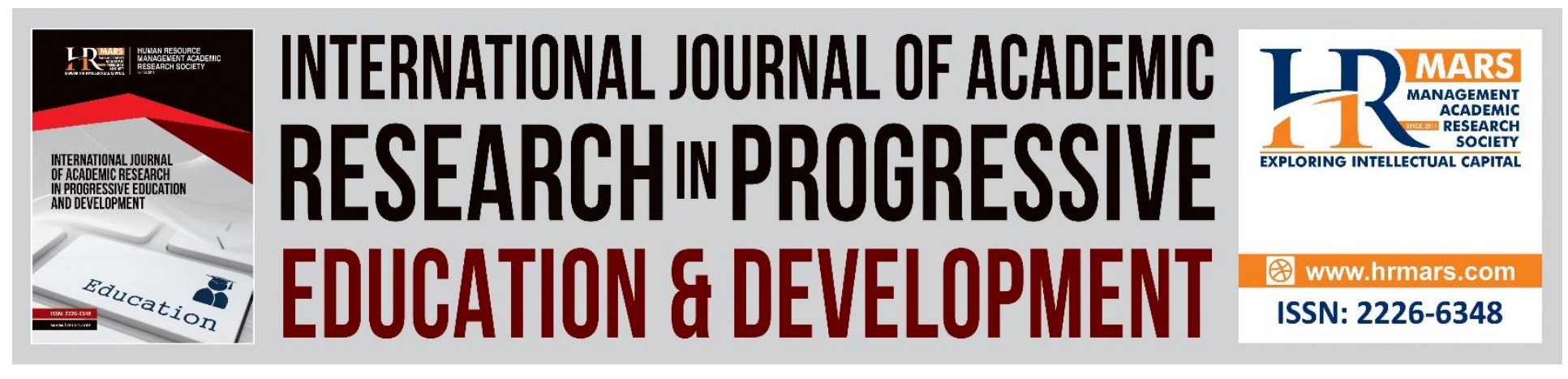

\title{
International Best Practices Analysis of Metadata Standard and Guidelines for the Development of Electronic Health Recordkeeping Metadata Standards of Malaysian Government Hospital System Integration
}

Seri Intan Idayu Shahrul Asari, Nurussobah Hussin, Ahmad Zam Hariro Samsudin

To Link this Article: http://dx.doi.org/10.6007/IJARPED/v7-i3/4363

DOI: $10.6007 /$ IJARPED/v7-i3/4363

Received: 02 June 2018, Revised: 21 June 2018, Accepted: 11 July 2018

Published Online: 20 July 2018

In-Text Citation: (Asari, Hussin, \& Samsudin, 2018)

To Cite this Article: Asari, S. I. I. S., Hussin, N., \& Samsudin, A. Z. H. (2018). International Best Practices Analysis of Metadata Standard and Guidelines for the Development of Electronic Health Recordkeeping Metadata Standards of Malaysian Government Hospital System Integration. International Journal of Academic Research in Progressive Education and Development, 7(3), 247-257.

Copyright: (C) 2018 The Author(s)

Published by Human Resource Management Academic Research Society (www.hrmars.com)

This article is published under the Creative Commons Attribution (CC BY 4.0) license. Anyone may reproduce, distribute, translate and create derivative works of this article (for both commercial and non-commercial purposes), subject to full attribution to the original publication and authors. The full terms of this license may be seen

at: http://creativecommons.org/licences/by/4.0/legalcode

Vol. 7, No. 3, July 2018, Pg. 247 - 257

http://hrmars.com/index.php/pages/detail/IJARPED

JOURNAL HOMEPAGE

Full Terms \& Conditions of access and use can be found at http://hrmars.com/index.php/pages/detail/publication-ethics 


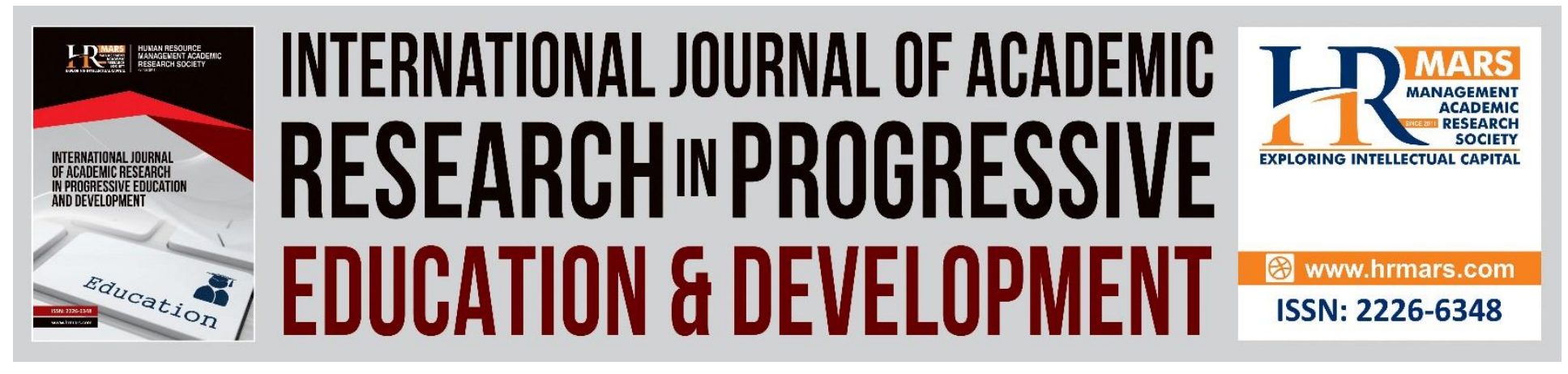

\title{
International Best Practices Analysis of Metadata Standard and Guidelines for the Development of Electronic Health Recordkeeping Metadata Standards of Malaysian Government Hospital System Integration
}

\section{Seri Intan Idayu Shahrul Asari, Nurussobah Hussin, Ahmad Zam Hariro Samsudin}

Faculty of Information Management, Universiti Teknologi MARA, UiTM Selangor, Shah Alam, Malaysia

\begin{abstract}
This paper highlights the demand towards recordkeeping metadata standardization for electronic health records system integration. It is aims to develop a recordkeeping metadata framework for electronic health records system integration in Malaysian government hospital. This paper explores surrounding the results of the data analysis regarding various international and national best practices of metadata standards and guidelines of electronic health records management across selected organizations in Unites States, United Kingdom, Australia, Switzerland, Canada, and Malaysia. The analysis main focus is to identify the metadata elements requirements in those various international and national best practices. There are three steps in the compilation of metadata elements requirement which includes identifying, analyzing and combining. The data collection method in done through Scopus analyze tools and document analysis. The results of the analysis reveal the leading countries that would be the benchmarks for the selection of international and national best practices. The investigation of national standard tells that there were no comprehensive metadata standard and guidelines develop and use as guidance in the management and integration of electronic health records system in Malaysian government hospital. Therefore, the researchers have to analyze six metadata standards to successfully identify the metadata elements of electronic records management and health records management that are relevant to the study. It is hoped that the compilation of the metadata elements required for electronic health records system integration will contribute to automated recordkeeping functionality and improved the capability of the system integration in EHR as well as empowered the benefit of recordkeeping management.
\end{abstract}


INTERNATIONAL JOURNAL OF ACADEMIC RESEARCH IN PROGRESSIVE EDUCATION AND DEVELOPMENT

Vol. 7, No. 3, July 2018, E-ISSN: 2226-6348 @ 2018 HRMARS

Keywords: Electronic Health Records, Record Keeping Metadata, Integration, Metadata Element, Information Management

\section{Introduction}

Standards and guidelines are important in monitoring the uniformity and serve as the basis guidance. However, one of the biggest challenges in the area of e-health standardization is the production of multitudinous e-health standards developed by numerous standardization bodies. The scenario resulted in the use of data sets which are non-standardized, where the data definition used were different and values varied. Hence the same data element means differently in different formats making data analysis difficult due to inconsistency of data, questionable data integrity and different data definitions (Health Informatics Centre, 2013). Due to that, this paper is aim to explore and provide an idea in selecting and benchmarking the standards and guidelines based on leading countries related to electronic health records system integration. More than that, the study focus on metadata elements and the researcher is attempting to combines the metadata elements based on well selected standards.

\section{Objectives}

The objective of this paper is to identify and analyse the various international and national best practices of metadata standards and guidelines for electronic health records management. The analyses are based on these following steps:

i. Analysis of leading country that involves in metadata, electronic health records and system integration.

ii. Analysis of international and national metadata standards and guidelines for electronic health records management.

iii. The combination of metadata elements required for electronic health records system integration.

\section{Methodology}

The methods used in this paper are analysis by using Scopus analyse tool and document analysis. The Scopus analyse tool is used to generate the statistics of publication which then illustrated in graph that explain the current status of related publication available in Scopus. The purpose of this process is to visualize the results into some structured manners that will give betters understanding to the researcher. The tool is available in Scopus search engine website which assist users further in finding relevant resources. The researcher used combination of relevant keywords related to the topics. Further details of keyword combination used are explained in the findings. The reason of choosing Scopus analyse tools is because every IPTA all over Malaysia are required to publish in Scopus to gain merit for further improvement in works or education or others similar. The data collection method for next objectives is document analysis. There are three steps in the compilation of metadata elements requirement which includes identifying, analysing and combining. Researcher has compared a long list of metadata elements that combine the selected standards being identified. All metadata elements available in the selected standards The summary of result is tabulated into table with highlights the main metadata elements separated into several entities types. 
Vol. 7, No. 3, July 2018, E-ISSN: 2226-6348 @ 2018 HRMARS

\section{Results and Discussions}

The analysis of related research is important in recognizing the relevancy of research topic and the area that has been explored by previous researchers. In this case, the analysis is to find out the leading countries that related closely with the topic of this study. The researcher used Scopus analyse tools to search related research that has been done and publish in Scopus. The researcher basically using three combinations of keywords. The keywords that has been used are as follows:

Keyword combination "metadata" AND "electronic health records" by country

The combination of keywords by the most popular country engage in the research topics. The results reveal that the United States are the highest contributors. Followed by Germany, Australia, Austria and United Kingdom. China is the next in line as contributor from Asia. Malaysia has not appeared in the results and that seem as the opportunity to contribute in the research field. The selection of best practices standard from these countries should be consider in future research. The following Figure 1 describe about the results.

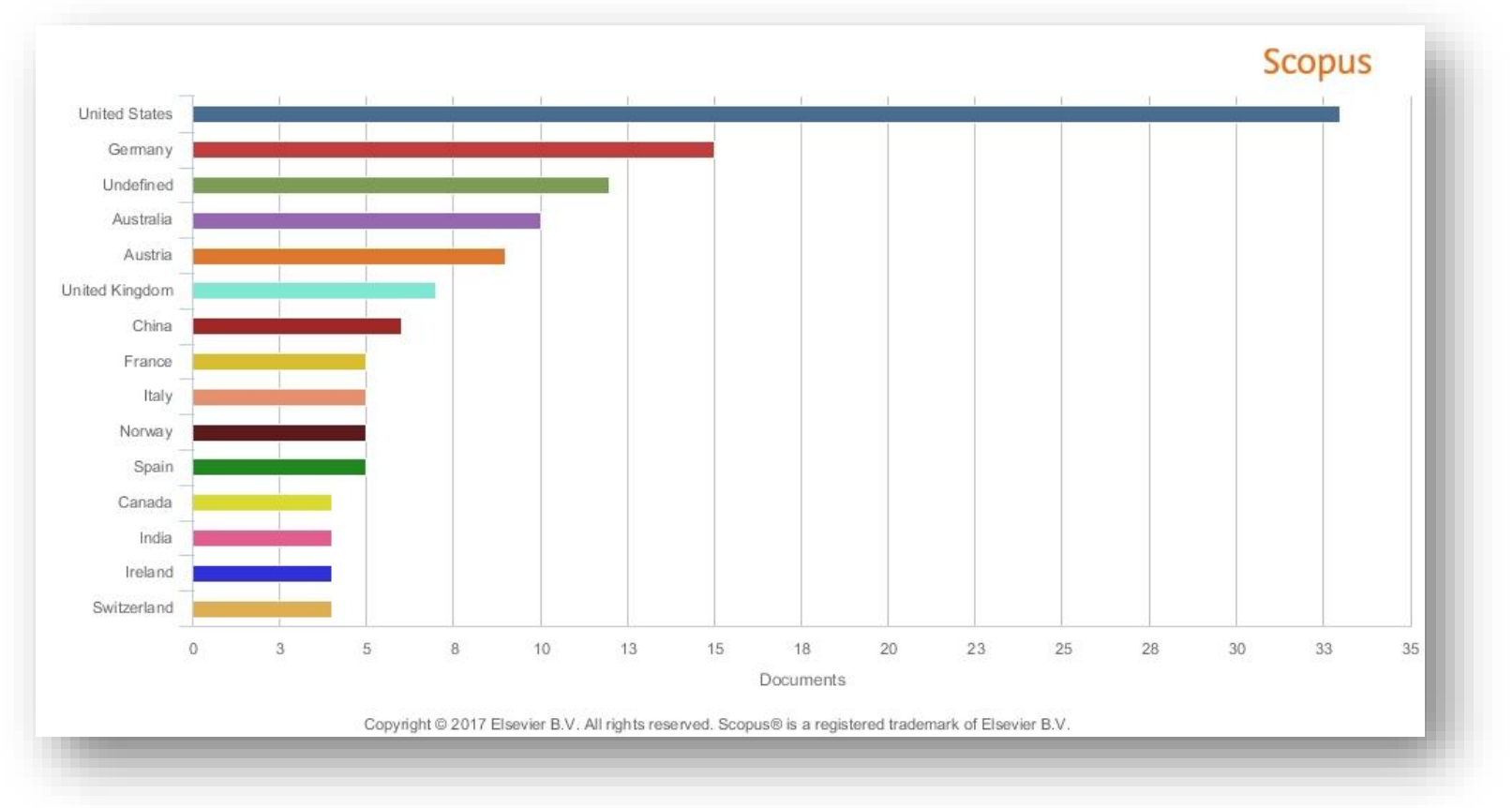

Figure 1: Keyword combination "metadata" AND "electronic health records" by country

Keyword combination "metadata" AND "system integration" by country

The search by country with another combination of keywords has reveal once again the United States as dominants from others countries. Next highest is Germany, China, United Kingdom, Spain and Poland. Once again United States is at the top and there is no doubt to includes standard and best practices from United States to be analyse in future research work. The other selection will be used to strengthen the constructed model which is considered to be fit in Malaysian environment. 
INTERNATIONAL JOURNAL OF ACADEMIC RESEARCH IN PROGRESSIVE EDUCATION AND DEVELOPMENT

Vol. 7, No. 3, July 2018, E-ISSN: 2226-6348 @ 2018 HRMARS

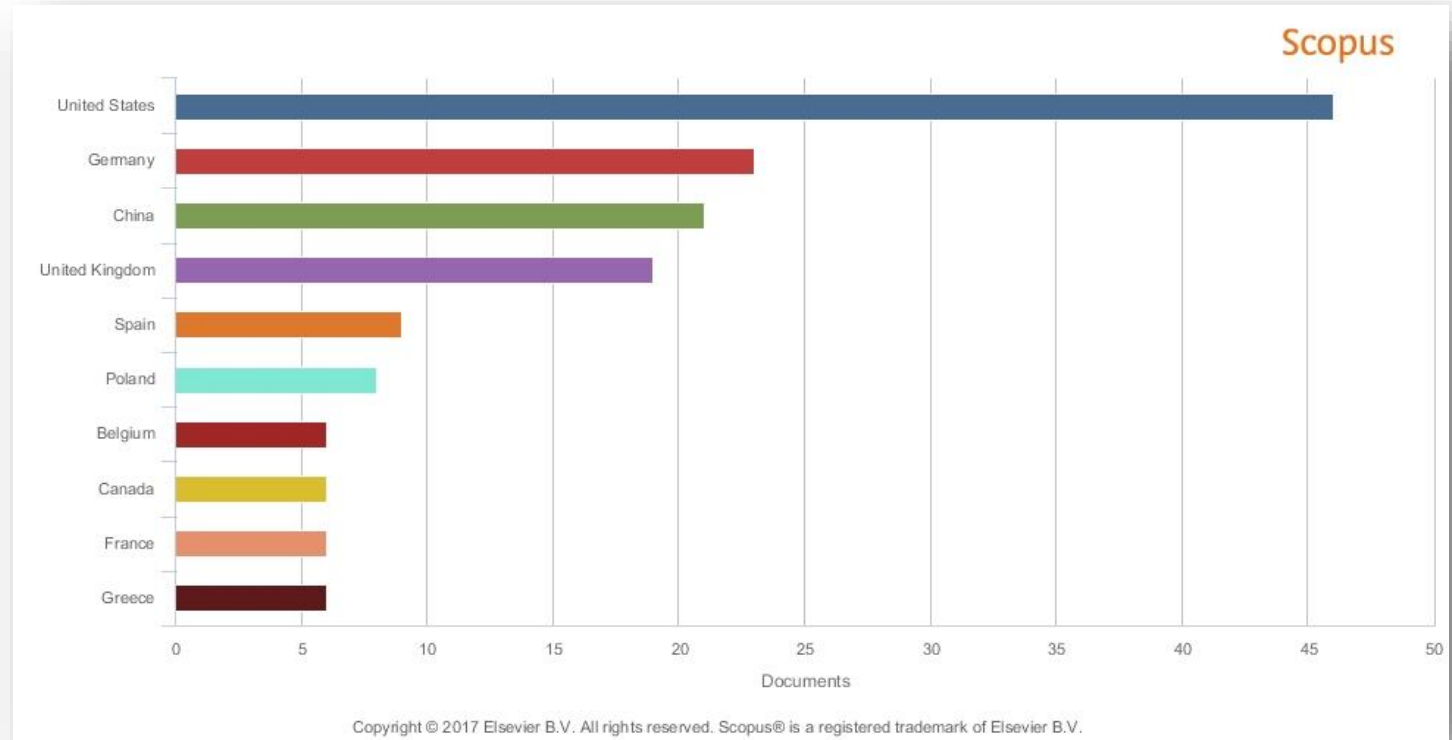

Figure 2: Keyword combination "metadata" AND "system integration" by country

Keyword combination "metadata" AND "(electronic health records" OR electronic medical records)" AND "system integrate" by country

More specific combination of keywords is then used for the third analysis. There is no doubt that United States is the leading countries from others in the selected topic. Next highest is Germany, Spain and United Kingdom and Canada and South Korea. Once again United States is at the top. These countries appear to be consistent in their involvement of the topics.

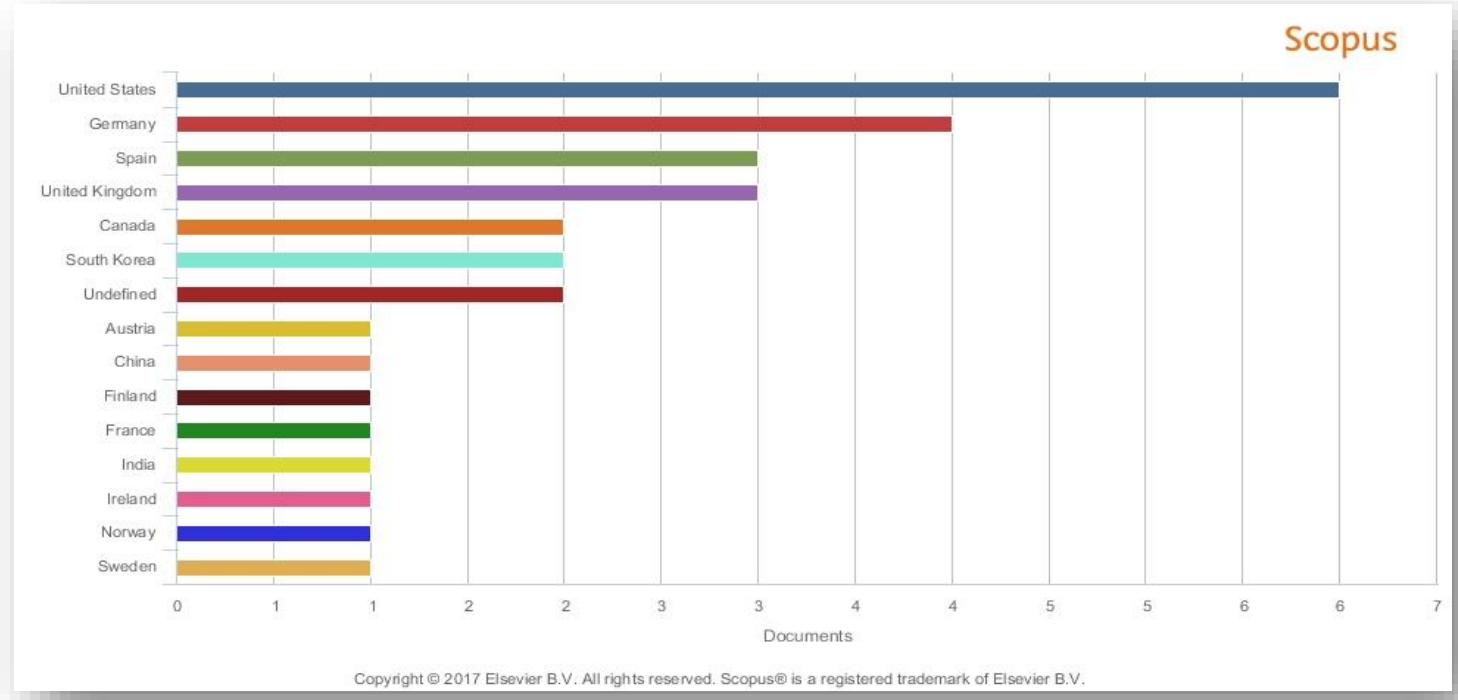

Figure 3: Keyword combination "metadata" AND "(electronic health records" OR electronic medical records)" AND "system integrate" by country 
The results of leading countries that involves in topic of study concern, has set the benchmarks for the researcher to explore and select the metadata standards and guidelines to be analysed. However, the findings are not only to be used alone without the comparison of with literatures, preliminary study and national bodies or local authorities in records management area in Malaysia. The selection of international metadata standards and guidelines that being analysed are as follows:

I. Minnesota recordkeeping metadata standard version 1.32015 (minnesota's information technology agency, 2015)

II. The international records management trust (the international council on archives and 2016)

III. Iso 23081-2 2009 (international organization for standardization, 2009)

IV. Queensland recordkeeping metadata standard and guideline version 1.12012 (queensland state archives, 2012)

V. Recordkeeping metadata standard (agrkms) version 2.22015 (national archives of australia, 2015)

VI. Iso 13119:2012 (health informatics) (sirim technical library, 2017)

VII. Records management metadata standard (government of canada) (gc rmms) 2006 (government on-line metadata working group, 2006)

United States appears to be dominant as the most country that engages into the topic of study. Therefore, the researcher decides to choose Minnesota Recordkeeping Metadata Standard version 1.32015 as the main document in the analysis. The following standard would support and added as it has others important criteria not included on the main documents. The Minnesota Recordkeeping Metadata Standard have details explanation of the obligation status of main elements as well as the sub elements. Researcher also influences by The International Records Management Trust (The International Council on Archives and 2016) as the main document to be analysed. The standard does not stand by itself. As mentioned in the module, an effective framework for the management of records, regardless of their physical form needs to be in place as an important pre-condition. In addition to that matters, several other ISO standards address the establishment of a framework and should be reviewed with ISO 23081(International Records Management Trust, 2016).

Based on that, ISO 23081 is counted to be includes in the analysis. The International Records Management Trust module also reports that, an excellent standard as well as a guide is, Queensland Recordkeeping Metadata Standard and Guideline, produced by the Queensland State Archives (2012). It identifies metadata elements required to manage records in accordance with best practice and provides guidance on implementation. It contains both a guideline on understanding and applying record-keeping metadata and a technical standard that identifies and defines metadata elements and specifies whether they are mandatory or optional. It is clearly written and the guidance it provides can be easily applied and/or adopted. It also provides guidance on implementing a metadata strategy, a topic that will be of particular interest to records professionals seeking a step-by-step approach to enhancing metadata management in their organisation. Researcher added the Australian standard to be part of the analysis as it also appears to be among of the leading countries that involves in such topics. 
INTERNATIONAL JOURNAL OF ACADEMIC RESEARCH IN PROGRESSIVE EDUCATION AND DEVELOPMENT

Vol. 7, No. 3, July 2018, E-ISSN: 2226-6348 @ 2018 HRMARS

The next selection of standard is Recordkeeping Metadata Standard (AGRkMS) version 2.2 2015. This standard is included because there are some metadata elements are not appearing in other standards. Other than that, this standard is more updated as it published on 2015 . The presentation of metadata elements and it applicability between entities is easier to understand by the researcher. ISO13119: 2012 is the only metadata standard related to medical and health informatics that the researcher found through the investigation. Others standard that complement the analysis is Canada Records Management Metadata Standard (Government of Canada) (GC RMMS) 2006.

The investigation on national metadata standard has been made through several organization through preliminary face-to-face interview, phone calls and email. The organization includes National Archive of Malaysia (NAM), Standard and Industrial Research Institute of Malaysia (SIRIM), Malaysian Administrative Modernisation and Management Planning Unit (MAMPU) and Ministry of Health Malaysia (MOHM). Information gathered from all of these organization reveals that there is no specific metadata standard that has been used as guidance in metadata management in government hospital. As mentioned by record manager MOHM, the guideline by MAMPU only covers the EDRMS that has been applied for administration management. It doesn't apply to EHR in hospital. National Archives of Malaysia stated that the available standard also for administration system. It doesn't apply to EHR because it categorized as business system in hospital.

As for SIRIM, researcher has contacted the librarian through email and search the ISO databases in SIRIM Technical Library (STS). Information gathered from the librarian reveal that only four MS that related with information and documentation. There includes MS 2473:2012, MS ISO 16175-1:2012, MS ISO 16175-2:2012, MS ISO 16175-3:2012. Research has analysed the content of the standard and found that it is not covers details information for metadata element. Further investigation is made through ISO Website that in STS. General search has listed 23,000 document standards that is related to metadata. However, researcher has gone through advanced search by combining specific term in order to narrow the result and to get specific relevance result. By using keyword "metadata element", only 12 standards have listed. Next the keyword is "metadata element"; "records" has listed 3 standards. Another keyword used is "metadata element; "medical" has found only 1 standard.

Through the finding, researcher has analysed those standard to find the relevancy of each standard for this study. Researcher found that only two related standards that is relevant which includes ISO 23081-2:2009 (metadata in general) and ISO 13119:2012 (health informatics). There is no Malaysian Standard (MS) that is related closely with ISO 23081-2:2009 and researcher decide that international standards is only resources to be used in analysing the best practices standard for metadata.

As the investigation is done in STS, researcher found that some other standard specifically related to medical system electronic health records (EHR) other than ISO 13119:2012. In order to confirm the relevancy of content, research has analysed ISO 13606, ISO 8601, ISO/TS 25238:2007. However, these standard is not detailing on metadata element. ISO 13606 is outlining for set of system code from a named term list for openEHR. Meanwhile, ISO 8601, is only explain about the arrangement for standard date and time. The ISO/TS 25238:2007 is for determining the security of software being used in hospital. Therefore, only two ISO standard that is relevance for this study which include ISO 23081-2:2009 (metadata in general) and ISO 13119:2012 (health 
Vol. 7, No. 3, July 2018, E-ISSN: 2226-6348 @ 2018 HRMARS

informatics)

After the identification of selected standard, researcher has analysed thoroughly each and every standard. Researcher has built long list of metadata main element and sub-elements separated by their entities types as well as the obligation status. Other than that, researcher found that entity types also play as important role in it applicability to be adopted in any system to be integrated. The entity types identified in the analysis is (1) record, (2) agent, (3) function or business, (4) mandate and (5) relationship. The researcher has combined all available metadata elements listed in those selected standards. The metadata elements that repeatedly appears in several standards is being combines and recorded as one metadata element. There are some elements would appear as main or sub-elements such as access and security classification. Researchers recorded the metadata element as main elements and combine both terms into one. The comparison of metadata element from the six selected standard has combined 50 metadata element for record entity, 14 for agent entity, 14 for function or business entity, 8 for mandate entity and 8 for relationship entity. The summary compilation of the main metadata elements is as below:

Table 1: The summary compilation of the main metadata elements

\begin{tabular}{|c|c|c|c|c|}
\hline RECORD & AGENT & $\begin{array}{c}\text { FUNCTION / } \\
\text { BUSINESS }\end{array}$ & MANDATE & RELATIONSHIP \\
\hline 1 Entity Type & 1 Entity Type & 1 Entity Type & 1 Entity Type & 1 Entity Type \\
\hline 2 Category & $\begin{array}{l}2 \text { Category / } \\
\text { Category } \\
\text { Type }\end{array}$ & $\begin{array}{l}2 \text { Category / } \\
\text { Category } \\
\text { Type }\end{array}$ & $\begin{array}{l}2 \text { Category / } \\
\text { Category } \\
\text { Type }\end{array}$ & $\begin{array}{l}2 \text { Category / } \\
\text { Category Type }\end{array}$ \\
\hline 3 Identifier & 3 Identifier & 3 Identifier & 3 Identifier & 3 Identifier \\
\hline 4 Name / Title & $\begin{array}{l}4 \text { Name / } \\
\text { Title }\end{array}$ & 4 Name / Title & 4 Name / Title & 4 Name / Title \\
\hline 5 Description & $\begin{array}{l}5 \\
\text { Description }\end{array}$ & 5 Description & 5 Description & 5 Description \\
\hline $\begin{array}{l}6 \text { Date / Date } \\
\text { Range }\end{array}$ & $\begin{array}{l}6 \text { Date / } \\
\text { Date Range }\end{array}$ & $\begin{array}{l}6 \text { Date / Date } \\
\text { Range }\end{array}$ & $\begin{array}{l}6 \text { Date / Date } \\
\text { Range }\end{array}$ & $\begin{array}{l}6 \text { Date / Date } \\
\text { Range }\end{array}$ \\
\hline \multicolumn{5}{|l|}{7 Subject } \\
\hline \multicolumn{5}{|l|}{8 Coverage } \\
\hline 9 Language & 7 Language & & & \\
\hline 10 Jurisdiction & $\begin{array}{l}8 \\
\text { Jurisdiction }\end{array}$ & 7 Jurisdiction & 7 Jurisdiction & \\
\hline $\begin{array}{l}11 \quad \text { Access / } \\
\text { Security } \\
\text { Classification }\end{array}$ & & $\begin{array}{l}8 \text { Access / } \\
\text { Security } \\
\text { Classification }\end{array}$ & $\begin{array}{lr}8 & \text { Security } \\
\text { Classification }\end{array}$ & \\
\hline \multicolumn{5}{|l|}{$\begin{array}{l}12 \text { Right } \\
\text { Management }\end{array}$} \\
\hline \multicolumn{5}{|l|}{13 Keyword } \\
\hline 14 Disposal & & & & \\
\hline
\end{tabular}


INTERNATIONAL JOURNAL OF ACADEMIC RESEARCH IN PROGRESSIVE EDUCATION AND DEVELOPMENT

Vol. 7, No. 3, July 2018, E-ISSN: 2226-6348 @ 2018 HRMARS

\begin{tabular}{|c|c|c|c|c|}
\hline 15 Type & & & & \\
\hline 16 Format & & & & \\
\hline 17 Relation & 9 Relation & 9 Relation & & \\
\hline 18 Extent & & & & \\
\hline 19 Medium & & & & \\
\hline 20 Integrity Check & & & & \\
\hline 21 Location & $\begin{array}{l}10 \text { Location } \\
\text { / Address }\end{array}$ & 10 Location & & \\
\hline $\begin{array}{ll}22 & \text { Document } \\
\text { Form } & \\
\end{array}$ & & & & \\
\hline 23 Precedence & & & & \\
\hline $\begin{array}{l}24 \text { Diseminating } \\
\text { Limiting Markers } \\
\text { (DLMS) }\end{array}$ & & $\begin{array}{l}11 \\
\text { Diseminating } \\
\text { Limiting } \\
\text { Markers } \\
\text { (DLMS) }\end{array}$ & & \\
\hline 25 Event History & $\begin{array}{l}11 \text { Event } \\
\text { History }\end{array}$ & $\begin{array}{ll}12 & \text { Event } \\
\text { History } & \\
\end{array}$ & & \\
\hline $\begin{array}{l}26 \text { Classification / } \\
\text { Aggregation Level }\end{array}$ & & & & \\
\hline 27 Agent & & & & \\
\hline 28 Use History & & & & \\
\hline $\begin{array}{l}29 \text { Preservation } \\
\text { History }\end{array}$ & & & & \\
\hline 30. Audience & & & & \\
\hline 31. Situation & & & & \\
\hline $\begin{array}{l}\text { 32. Clinical } \\
\text { process stage }\end{array}$ & & & & \\
\hline $\begin{array}{l}\text { 33. Evidence } \\
\text { grading }\end{array}$ & & & & \\
\hline $\begin{array}{l}\text { 34. Recommended } \\
\text { strength }\end{array}$ & & & & \\
\hline 35. Risk class & & & & \\
\hline 36. Status & & & & \\
\hline 37. Publisher & & & & \\
\hline 38. Contributor & & & & \\
\hline 39. Citation & & & & \\
\hline 40. Source & & & & \\
\hline 41. Addressee & & & & \\
\hline 42. Approved & & & & \\
\hline $\begin{array}{l}\text { 43. Compound } \\
\text { record link }\end{array}$ & & & & \\
\hline 44. Container & & & & \\
\hline
\end{tabular}


INTERNATIONAL JOURNAL OF ACADEMIC RESEARCH IN PROGRESSIVE EDUCATION AND DEVELOPMENT

Vol. 7, No. 3, July 2018, E-ISSN: 2226-6348 @ 2018 HRMARS

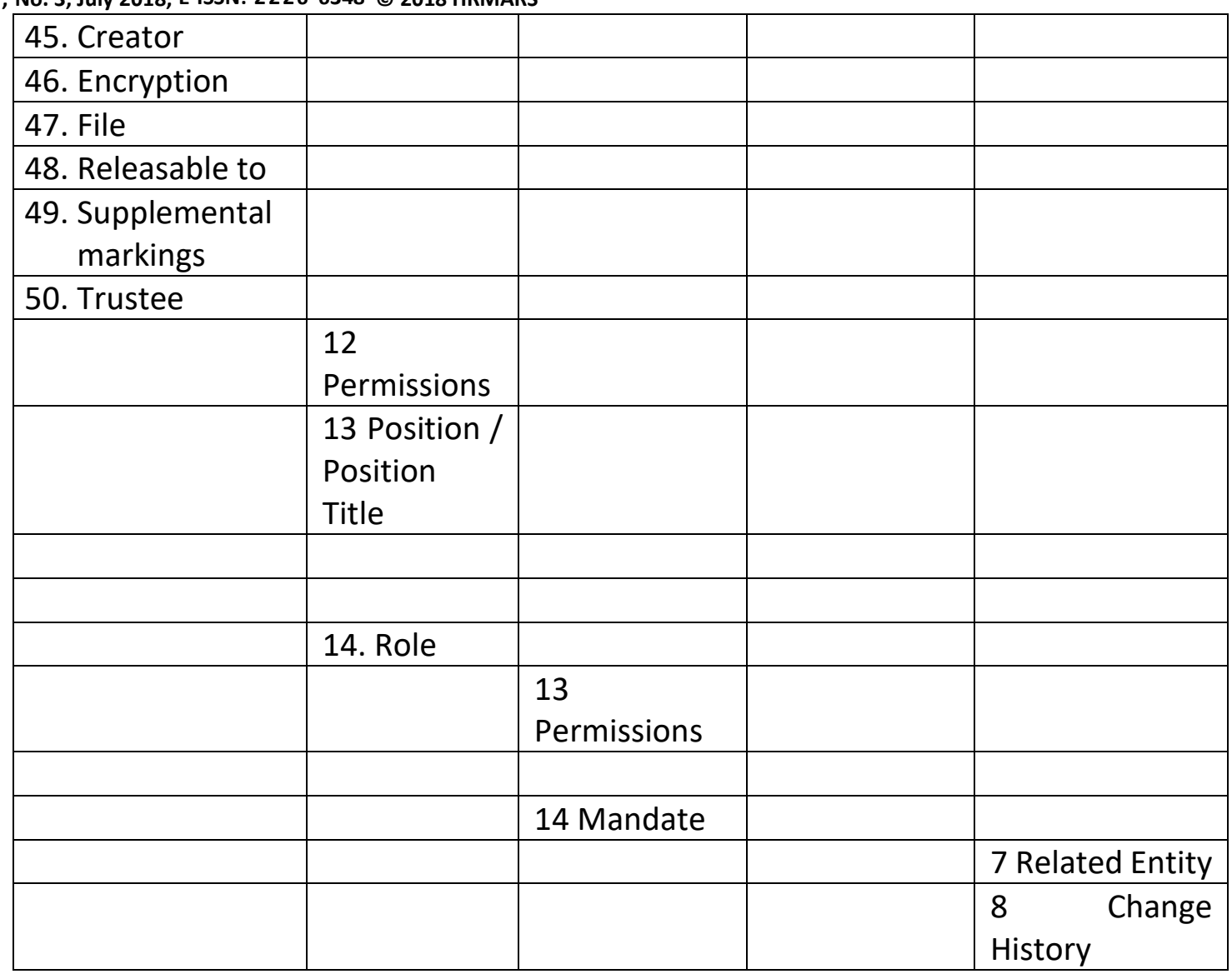

\section{Conclusion}

As for the conclusion, the finding of this study would benefit the future research in finding basis for benchmarking the leading countries in metadata standards and guidelines selections. However, the findings only limited to the scope of study which related to electronic health records system integration. The compilation of metadata elements also would contribute towards the framework development for the most required metadata elements in integration electronic health records system. It is hoped that the compilation of the metadata elements required for electronic health records system integration will contribute to automated recordkeeping functionality and improved the capability of the system integration in electronic health records (EHR) as well as empowered the benefit of recordkeeping management.

\section{References}

Government On-Line Metadata Working Group. (2006). Government of Canada Records Management Metadata Standard. Library and Archives Canada. Retrieved from https://www.collectionscanada.gc.ca/obj/007002/f6/007002-5001-e.rtf

Health Informatics Centre. (2013). HIMS Blueprint (Vol. 13). Retrieved from http://www.moh.gov.my/images/gallery/publications/hi/HIMS Blueprint.pdf

International Organization for Standardization. (2009). International Standard. Time. https://doi.org/10.1109/IEEESTD.2007.4288250

International Records Management Trust. (2016). Managing Metadata to Protect the Integrity of 
INTERNATIONAL JOURNAL OF ACADEMIC RESEARCH IN PROGRESSIVE EDUCATION AND

DEVELOPMENT

Vol. 7, No. 3, July 2018, E-ISSN: 2226-6348 @ 2018 HRMARS

Records, (May).

Minnesota's information technology agency. (2015). Title : Minnesota Recordkeeping Metadata Standard Table of Contents, 1(March), 1-101.

National Archives of Australia. (2015). Australian Government Recordkeeping Metadata Standard. National Archives of Australia (Vol. XXXIII). https://doi.org/10.1007/s13398-0140173-7.2

Queensland State Archives. (2012). Queensland recordkeeping metadata standard and guideline. 